stends, they cannot, Take my own case, for instance: I was, more than twenty-five years ago, anticled to a pure surgeon for six years, with the intention of practising surgery alone; but, from circumstances, I became a general practitioner. Now.I would willingly submit myself to a fair practical examination from the Apothecaries' Company, but of course, not having been apprenticed to any member of their Society, it would be nseless to offer. myself. No doubt, there are many other members of the College similarly situated. Let the Apathecaries' Company, therefore, imitate the College of Phycicians, and throw open their doors, under certain regulations, to all M.R.C.S. of a certain standirg, who are willing to enter them: Hundreds, no doubt, would axail themselves of the opportunity; not that it would be attaching any additional honours to their names, for who, at the present day, takes pride in calling himself an apothecary-in being compelled, at all times and all hours, to malke up the prescriptions that any member of the College of Physicians may choose to direct to him? In conclusion, I cannot help observing, that if a member of the College of Surgeons has no right to dispense medicines, surely the mere apothecary has no right to practise surgery, or to style himself a surgeon; and if the one is to be prosecuted, it does not appear like equal justice that the other should pass unscathed. The College of Surgeons has received enormous sums from its members, and, in return, all its exertions have as yet been confined to degrading the majority for the purpose of exalting the few. It is now, however, imperatively called upon to interfere on the behalf of those members situated as I have described; and surely it has sufficient influence to obtain the assent of the Apothecaries? Company to the proposed arrangement, though it would be much better that the College of Surgeons took upon itself the power of granting full licence to practise all branches of the profession-of course, under proper examinations.

The general practitioner almost invariably designates himself surgeon, and by that title always gives his evidence in all courts of law; why not, therefore, do away with the objectionable term apothecary altogether, letting the profession be known only as surgeons and physicians?

I am, Sir, your very obedient servant,

A Practitioner of Mant Years' Standina.

\section{COD-LIVER OIL.}

To the Editor of THE LANCET.

SrR,-I send you, at your request, the report of an analysis which has been made of Messrs. Langtons' cod-liver oil. I may suggest that the chief points in favour of this oil are, first, its ascertained freedom from adulteration; secondly, its containing in due proportion all the known constituents of cod-liver oil in general; and thirdly, its being, beyond comparison, the most agreeable both in taste and odour, or rather, the only one that is agreeable at all. To find this last recommendation in that class of oil (the pale) which contains the greatest quantity of iodine, would incline us at once to give it preference for trial in rheumatism, phthisis, and scrofula; for though the amount of iodine even in the pale oil is but small, yet the peculiar combination in which it exists as part of an animal product may well be thought capable of giving it an efficacy beyond what its mere quantity would indicate, as occurs in the case of chalybeate and other mineral waters, which have a power over disease altogether disproportioned and superior to the amount of their medical constituents. And with the confession of even so intelligent an observer as De Jongh, that the substances (as gaduine) peculiar to cod-liver oil are in all likelihood medicinally inert, there seems fair ground for assuming that the iodine most abundant in the pale oil plays an important part in the now frequent cases of cure, more especially as iodine in its mineral forms has a well-proved influence over those very diseases which most readily yield to the oleum aselli.

The liberality and spirit of the Messrs. Langton, in sending over to Newfoundland a first-rate extractor of the oil, so as to insure its being obtained in the best manner, and from the fresh liver-and in their procuring a minute analysis of the article by such chemists as Mr. Aikin and Dr. Taylor, form an additional claim on their behalf to the support of the profession.

I have the honour to be, Sir, your most obedient servant, Knightsbridge, Sept. 27, 1849. F. A. B. Bonney. (COPY.)

We hereby certify that we have examined a specimen of cod-liver oil, transmitted to us for this purpose by Messrs. Langton Brothers and Seott.
The oil is of a pale yellow colour, with a slight but not offensive fishy odour, and is free from any disagreeable taste. It is very fluid, and in consistency and general appearance resembles good Florence oil. Its speeific gravity at $61^{\circ}$ Fahr. is 0.924 . At the temperature of $14^{\circ} \mathrm{Fahr}$. the stearine is deposited, and the liquid oleine when poured off; the stearine becomes gelatinous at $10^{\circ} \mathrm{Fahr}$ : It contains no free acid, and is perfectly neutral to re-agents. In ether it is wholly soluble, not leaving behind any deposit or sediment. Alcohol of 0.815 dissolves it in small quantity. This alcoholic solution is quite colourless, and does not produce any blue colour on starched paper immersed in it, thus proving that no iodine had been added to the oil. Sulphuric acid produces in the oil a rich violet-pink colowr, indicating the presence of cholic acid, and therefore of biliary matter. A portion of the oil was saponified by a solution of pure soda, and the soap thus prepared was charred in a close vessel. This residue, when boiled in water, gave a colourless solution, which was found by appropriate tests to contain iodine. The quantity of iodine per cent., according to the nearest calculation which could be made, amounted to .027 or $\frac{1}{36}$ part by weight. This corresponds to the proportion assigned by other analysts.

From these and other results we believe that the sample sent to us is a genuine and unsophisticated specimen of codliver oil.

We are likewise of opinion, from its purity, and the absence of any unpleasant odour or flavour, that it is preferable for medicinal use to those samples of cod-liver oil which have hitherto come under our notice.

(Signed) Arthur AIKIN,

Alfred Swayne Taylor, M.D., F.R.S. Professors of Chemistry in Guy's Hospital.

Chemical Laboratory, Guy's Hospita1, Sept. 25, 1949.

\section{THE LATE ASTON KEY, ESQ., F.R.S.} To the Editor of The LANCET.

SrR,-The sorrow evinced by the death of Mr. Aston Key is sufficient evidence to show in what light this eminent surgeon was regarded both by the profession and the public; and makes it too clear that a great loss has been sustained, and that his worth was duly estimated. Having seen much of Mr. Key for a few years past, I think it would not be uninteresting to your readers if, in addition to the account of his public career, which you gave in a former number, $I$ were to offer a few remarks on his character, which might bring to light any peculiar qualities with which his mind was endowed, and enable us to discover what gave hin that power, which placed him in such an honourable eminence, and that strength to retain it, until death, cloaked under a dire pestilence, came and struck him down.

If a stranger for the first time had met $\mathrm{Mr}$. Key, and observed his figure, tall, upright, and commanding, he would have at once declared that he was looking upon no ordinary man, but upon one accustomed to rule-upon one from whom he must involuntary shrink back and feel himself inferior. Nor would this first impression, from external appearances alone, have deceived him; for let him but mark the first utterances of his lips, and it would be incontestably proved that he was one who habitually carried with him an air of superiority, a right to command, which tinctured all his words and actions, and which, in fact, as distinguished from others, formed the main feature of his character. However friendly you might become, he ever made you feel your inferiority; and even if, from his elevated sphere, he perchance descended to a more convivial mood, he was always ready to assert his superiority, and to retrace his steps to that height from which he had for a moment stepped. Thus was there always an unfathomable gulf between him and his admirers. The question naturally suggests itself-how was this superiority acquired? How much of it was to be attributed to a natural force of character? How much to a conscious knowledge of merit, and how much to that praise lavished on him by his brethren, and acquired by time? We shall find that the truth is evolved from the consideration of all these sources.

There can be no doubt that knowledge is power; but it does not necessarily follow that its possessor always has this superior influence so marked in him that it can be traced in all his footsteps, and cause him to be recognised by every one as if by intuition.

As regards the subject of these remarks, we may truly say that Mr. Key's knowledge of his profession was in the fullest sense profound. He had not studied surgical disease in a large hospital in vain. Nothing worthy to be acquired could have escaped his quick and penetrating mind. Add to 